\title{
Evaluation of SARS-CoV-2 in Indoor Air of Sina and Shahid Beheshti Hospitals and Patients' Houses
}

\author{
Farid Azizi Jalilian ${ }^{1}$. Ali Poormohammadi ${ }^{2,3} \cdot$ Ali Teimoori $^{1} \cdot$ Nastaran Ansari $^{1} \cdot$ Zahra Tarin $^{2}$. \\ Farshid Ghorbani Shahna ${ }^{3}$. Ghasem Azarian ${ }^{4} \cdot$ Mostafa Leili $^{4}$. $\cdot$ Mohammadreza Samarghandi ${ }^{4}$. \\ Mahyar Motaghed ${ }^{5} \cdot$ Amir Nili Ahmadabadi $^{6} \cdot$ Mohammad Sadegh Hassanvand $^{7,8}$
}

Received: 19 August 2021 / Accepted: 9 February 2022 / Published online: 25 February 2022

(C) The Author(s), under exclusive licence to Springer Science+Business Media, LLC, part of Springer Nature 2022

\begin{abstract}
Side by side air sampling was conducted using a PTFE filter membrane as dry sampler and an impinger containing a suitable culture medium as a wet sampler. Most of the samples were collected from two hospitals and few air samples were collected from private houses of non-hospitalized confirmed COVID-19 patients. The collected air samples were analyzed using RTPCR. The results indicated that all air samples collected from the hospitals were PCR negative for SARS-CoV-2. While two of four air samples collected from the house of non-hospitalized patients were PCR positive. In this study, most of the hospitalized patients had oxygen mask and face mask, and hence this may be a reason for our negative results regarding the presence of SARS-CoV-2 in indoor air of the hospitals, while non-hospitalized patients did not wear oxygen and protective face masks in their houses. Moreover, a very high concentration of particles in the size range of droplet nuclei $(<5 \mu \mathrm{m})$ was identified compared to particles in the size range of respiratory droplets $(>5-10 \mu \mathrm{m})$ in the areas where patients were hospitalized. It can be concluded that using face mask by patients can prevent the release of viruses into the indoor air, even in hospitals with a high density of patients.
\end{abstract}

Keywords SARS-CoV-2 $\cdot$ Indoor air $\cdot$ Particle $\cdot$ Transmission $\cdot$ Hamadan

\section{Introduction}

Currently, the emergence and epidemic of the new human coronavirus (SARS-CoV-2) has become an international concern and notified to the World Health Organization (WHO) by the Wuhan Municipal Health Commission on 31

Mostafa Leili

mostafa.leili@gmail.com

1 Department of Virology, Faculty of Medicine, Hamadan University of Medical Sciences, Hamadan, Iran

2 Department of Occupational Health Engineering, School of Public Health, Hamadan University of Medical Sciences, Hamadan, Iran

3 Center of Excellence for Occupational Health, Occupational Health and Safety Research Center, School of Public Health, Hamadan University of Medical Sciences, Hamadan, Iran

4 Department of Environmental Health Engineering, School of Public Health and Research Center for Health Sciences, Hamadan University of Medical Sciences, Shaheed Fahmideh Ave., 6517838695 Hamadan, Iran
December 20,191 (Holshue et al., 2020). In humans, SARS$\mathrm{CoV}-2$ can cause illness ranging from the common cold to more severe diseases. Coronavirus disease (COVID-19) is an infectious disease caused by this novel virus. Human-tohuman transmission can also occur during the incubation period, and this feature has obviously increased its spread

5 Department of Neurology, Faculty of Medicine, Hamadan University of Medical Sciences, Hamadan, Iran

6 Department of Pharmacology and Toxicology, School of Pharmacy, Hamadan University of Medical Sciences, Hamadan, Iran

7 Centre for Air Pollution Research (CAPR), Institute for Environmental Research (IER), Tehran University of Medical Sciences, Tehran, Iran

8 Department of Environmental Health Engineering, School of Public Health, Tehran University of Medical Sciences, Tehran, Iran 
compared with other viruses causing respiratory infections (Morawska \& Cao, 2020). In general, viral respiratory infections are spread from person to person through direct contact with infected person via inhalation of respiratory droplets containing virus particles or indirect contact with contaminated surfaces. In direct contact, infected persons release respiratory droplets containing a high load of viruses by coughing and sneezing (Shereen et al., 2020). The respiratory droplets often defined as particles having a diameter greater than $5 \mu \mathrm{m}$ and are large enough to fall to the ground rapidly after being produced. According to the WHO guidelines, respiratory infections are released from patients in two different sizes, including particles $>5-10 \mu \mathrm{m}$ in diameter referring to as respiratory droplets that remain in the air for a short time and can travel a short distance, and particles $<5 \mu \mathrm{m}$ in diameter that are referred to as droplet nuclei, where can remain suspended in air for considerable periods of time, allowing them to be transmitted over distances $>1 \mathrm{~m}$ (Belosi et al., 2021; Chartier \& Pessoa-Silva, 2009; WHO, 2020). According to the previous studies, the size of droplet nuclei caused by sneezing, coughing and talking depends on the generation process and environmental conditions (Dhand \& Li, 2020; WHO, 2020). Various environmental conditions such as air velocity, humidity and temperature affect dispersion the particles containing the virus in the air (Poormohammadi \& Azarian, 2020). Based on the WHO reports, the predominant mode of transmission of SARS CoV-2 is attributed to direct contact of mucous membrane with respiratory droplets from either infected people or fomites (Zheng, 2020). Based on the previous studies on the SARS-CoV-2 virus, its airborne transmission can occur in indoor spaces, but its occurrence is not significant in outdoor air. Most airborne transmission occurs at close proximity (Belosi et al., 2021). It has been also reported that it can remain viable for several days on various surfaces. A recent study on the stability of SARS-CoV-2 virus in aerosols and various surfaces showed that SARS-CoV-2 remained viable in aerosols for $3 \mathrm{~h}$ and was more stable on various surfaces such as plastic and stainless steel. They also detected the viable virus up to $72 \mathrm{~h}$ after contacting these surfaces. However, in the mentioned study, the viral load was gradually deceased in the surfaces over time (van Doremalen et al., 2020).

Due to insufficient information about this virus, there are contradictory evidences regarding the main mode of transmission of virus causing COVID-19, the predominant routes of transmission of this disease have not yet been fully understood. As mentioned, airborne transmission is different from droplet transmission as it refers to the presence of microbes within droplet nuclei, which are generally considered particles smaller than $5 \mu \mathrm{m}$ in diameter, which can remain in the air for long periods of time and be transmitted to others over distances greater than $1 \mathrm{~m}$ (WHO, 2020). Until now, some studies reported that the COVID-19 virus can be detected in the air and hence, it can be spread as an airborne virus (Kenarkoohi et al., 2020; van Doremalen et al., 2020). The high transmission rate of SARS-CoV-2 virus emphasizes that it can be spread through breathing air as an airborne agent (WHO, 2020). Despite this evidence, there is no clear conclusion regarding its airborne transmission to prevent it from being transmitted through indoor air. It has been recommended that after discharge, COVID-19 patients should isolate themselves, continue to self-monitor their health at their home for 2 weeks, wear a mask, live in a single room with appropriate ventilation, reduce close contact with other family members, keep hands clean and avoid outdoor activities. Thus, it is necessary to assess the private house status and the extent to which the mentioned criteria are followed. Our literature search revealed that not many data are reported for private houses with discharged COVID-19 patients from the hospitals, thus the results of this research could reflects the infectious status of the private houses of COVID-19 patients and help decision makers about patient follow-up visit intervals as the required criteria should be considered when deciding whether a confirmed COVID-19 case can be discharged from hospitals. Moreover, identifying the presence of viruses in the indoor air of infected people can help control the disease and prevent its transmission to other people. Therefore, further studies are necessary to examine its presence in air in different environments. With full knowledge of transmission modes of this new virus, effective preventive measures can be performed to prevent its widespread transmission and to control this pandemic. Thus, the present study aimed at the determination of the level of virus load in indoor air of two major hospitals dedicated to COVID-19 patients in Hamadan, Iran. Moreover, some air samples were taken from indoor air of the houses of non-hospitalized patients. These patients with SARS-CoV-2 infection were confirmed by PCR analysis and clinical symptoms and did not require hospitalization. They were quarantined in their house under medical supervision.

\section{Material and Methods}

\section{Sampling Sites}

In the present study, air sampling was conducted at different wards, including patient rooms, infectious wards with high density of confirmed COVID-19 patients, and intensive care unit (ICU) of Sina and Shahid Beheshti hospitals, in Hamadan, Iran. In the first step, air sampling procedure was performed in an infectious ward of Sina Hospital with a relatively high patient density. The patients with SARSCoV-2 infection were confirmed by PCR analysis and clinical symptoms. Most of the patients had oxygen mask but 
did not use it constantly. Some patients were coughing and talking with mobile phone during the sampling period. We used a similar sampling procedure for two families that were confirmed for SARS-CoV-2 virus and quarantined at their houses with two and five infected family members, respectively. A total of 30 air samples were collected from Sina (20 samples) and Beheshti (10 samples) hospitals using filtration and impinger techniques as well as four samples from patient houses.

\section{Samplers}

Since in the previous studies, it has been reported that dry sampling methods may damage the target virus (Rahmani et al., 2020), in this study, to decrease possibly damage to the trapped virus and increase the chances of detecting the presence of the SARS-CoV-2 virus in the indoor air, two different kinds of air samplers were applied including $0.3 \mu \mathrm{m}$ pore size polytetrafluoroethylene (PTFE) in conjunction with a 3-piece cassette as dry sampler and an impinger containing a suitable culture medium for the virus as a wet sampler. Side by side sampling was performed in each sampling site with both the wet and dry samplers. In the present study, a Viral Transport Medium (VTM) was used as liquid impinger for trapping the virus from the hospital indoor air. The VTM was prepared by Department of Virology in Hamadan University of Medical Sciences. The VTM contained DMEM (Dulbecco's Modified Eagle Medium), bovine serum albumin (BSA), penicillin, and streptomycin solution. In order to sample the indoor air with the wet sampler, the impinger was attached to an average flow personal sample pump, and $20 \mathrm{~mL}$ of the prepared VTM was poured into the impinger. A trap was also used with the impinger containing the VTM solution to prevent impinger liquids from being drawn into the sample pump. The sampling flow rate was set at $1.2 \mathrm{~L} / \mathrm{min}$, and the air sampling was performed for $3 \mathrm{~h}$. Unlike previous studies, in this study, there was no foam formation during sampling and no need to add antifoaming agent. In the use of the dry sampler, PTFE filter membrane was placed inside a cassette, and as mentioned above, the sampling set was used with a flow rate of $1.2 \mathrm{~L} /$ min for $3 \mathrm{~h}$. In this study, side by side sampling with the both wet and dry samplers was conducted in a same sampling site to find the appropriate sampling method and

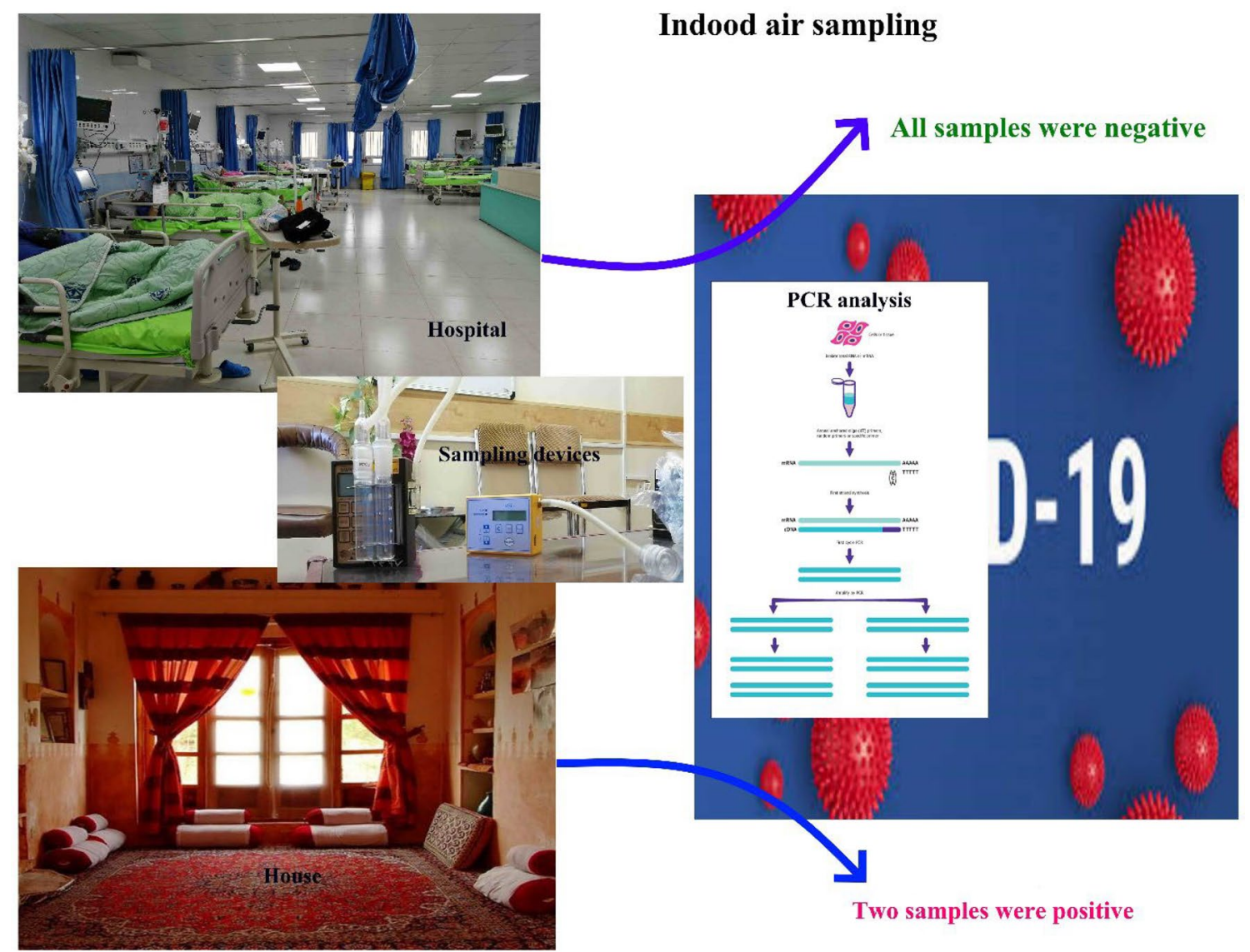

Fig. 1 Indoor air sampling of SARS-CoV-2 virus 
increase the chances of trapping potential viruses in the air. Average flow sampling pumps were used for air sampling (SKC Inc. Universal Pump PCXR4-Personal Air Sampling Pump) with PTFE and impinger samplers. Figure 1 shows the sampling devices and locations. Sampling was performed from a height of $1.5 \mathrm{~m}$ above the ground. For this reason, the sampling set was placed on a movable table and sampling was performed at different distances from the patient's bed.

\section{Sampling Conditions and Environmental Factors}

In this research, due to the possible influence of some environmental parameters on sampling results, the levels of temperature and relative humidity, ventilation status, and $\mathrm{CO}_{2}$ concentrations were recorded during the sampling period. A GRIMM portable aerosol spectrometer (Model 1.108, Germany) was applied for measuring the particle number concentrations (PNC) in the two different sizes including $>5-10 \mu \mathrm{m}$ and $<5 \mu \mathrm{m}$ in diameter.

\section{RT-PCR Test}

In the present study, the GeneAll ${ }^{\circledR}$ RibospinTM vRD II was used for the isolation of RNA from the impinger liquid and filter. The RNA extraction was conducted according to the manufacturer's instructions. Briefly, $250 \mu \mathrm{L}$ of buffer VL was added into a $2 \mathrm{~mL}$ micro centrifuge tube. Afterward, $150 \mu \mathrm{L}$ of the impinger liquid was transferred into a $1.5 \mathrm{~mL}$ micro centrifuge tube, and then stirred thoroughly for $10 \mathrm{~s}$. Next, the mixture was incubated at room temperature for $10 \mathrm{~min}$. Then, $350 \mu \mathrm{L}$ of buffer RB1 was added into the mixture and stirred thoroughly using a magnetic mixer for $10 \mathrm{s.} 750 \mu \mathrm{L}$ of the resulting mixture was added into a spin column and then centrifuged at $\geq 10,000 \mathrm{~g}$ for $30 \mathrm{~s}$ at room temperature. The pass-through was discarded and reinserted the spin column back into the same collection tube. Next, $500 \mu \mathrm{L}$ of buffer RNW added to the spin column and centrifuged at $\geq 10,000 \mathrm{~g}$ for $30 \mathrm{~s}$ at room temperature. The last step of centrifuge was again repeated. The pass-through was again discarded and reinserted the spin column back into the same tube. Subsequently, in order to remove residual wash buffer, the resulting mixture was centrifuged at full speed for an additional $1 \mathrm{~min}$ at room temperature. Then, the spin column was transferred into a DNase \& RNase free vial $(1.5 \mathrm{~mL}) .50 \mu \mathrm{L}$ of Nuclease-free water was added to the center of the membrane in the spin column for 1 min followed by centrifuge at $\geq 10,000 \times g$ for $1 \mathrm{~min}$ at room temperature. Eventually, the resulting nucleic acids was kept at $-70{ }^{\circ} \mathrm{C}$ until it was tested.
In this research, the SARS-CoV-2 was detected by qualitative method using diagnostic Kit (Sansure Biotech, Belgium). In this multiplex Kit, the ORF1ab and $\mathrm{N}$ genes of SARS-CoV-2 and an internal control (IC) are included in order to detect the SARS-CoV-2 virus. Briefly, $5 \mu \mathrm{L}$ of RNA was amplified in a $20 \mu \mathrm{L}$ reaction containing $13 \mu \mathrm{L}$ of master mix and $2 \mu \mathrm{L}$ of PCR enzyme mix (RT enzyme and Taq Enzme). Reactions were first incubated at $50{ }^{\circ} \mathrm{C}$ for $15 \mathrm{~min}$, followed by $95{ }^{\circ} \mathrm{C}$ for $15 \mathrm{~min}$. Finally, reactions were then thermal-cycled for 45 cycles $\left(95^{\circ} \mathrm{C}\right.$ for $15 \mathrm{~s}, 55^{\circ} \mathrm{C}$ for $30 \mathrm{~s}$ ).

\section{Results and Discussion}

In the present study, for air sampling of SARS-CoV-2 in indoor air of patient's rooms, dry (PTFE filter) and wet (impinger containing a viral culture) samplers were simultaneously used in Sina and Shahid Beheshti hospitals in Hamadan city, which dedicated to COVID-19 patients (Fig. 1). Approximately, 100 and 65 suspected COVID19 patients were hospitalized in Sina and Shahid Beheshti hospitals, respectively during the sampling period. A total of 30 air samples were collected from Sina (20 samples) and Beheshti (10 samples) hospitals regarding filtration and impinger techniques along with four samples from patient houses. Environmental factors that may influence COVID-19 virus transmission through the air were measured during the sampling period. The ranges and means of these factors are presented in Tables 1 and 2. As can be seen, the temperature in the studied wards of the two hospitals was in the range 22.4-28. $1^{\circ} \mathrm{C}$. Moreover, the relative humidity of the studied wards was in the range $26.5-52.6 \%$. In a related study, it has been reported that high temperature and high relative humidity play synergistic effects on the inactivation of SARS-CoV, while lower temperatures and low humidifies increase the viability of SARS-CoV virus (Chan et al., 2011). Ventilation can also affect both accumulation and concentration of microbiological agents (Onmek et al., 2020). In addition, in a previous study, it was shown that very high concentrations of $\mathrm{CO}_{2}$ (about $1500 \mathrm{ppm}$ ) can inactivate the viruses (Sanchis et al., 2019). In this regard, the concentration of $\mathrm{CO}_{2}$ was also measured and reported in Table 1 . However, all the air samples were negative for SARS-CoV-2, which might be due to low numbers of confirmed COVID-19 patients, ventilation status and room volume, so we are not able to discuss its effects on the virus viability.

According to the last information of transmission modes of the COVID-19 virus by WHO, respiratory infections can be generally transmitted through respiratory droplets that are larger than 5-10 $\mu \mathrm{m}$ in diameter and droplet nuclei that are less than $5 \mu \mathrm{m}$ in diameter (WHO, 2020). According to current evidence, COVID-19 virus is primarily 
Table 1 Additional information on environmental status of patient rooms with confirmed COVID-19

\begin{tabular}{|c|c|c|c|c|c|c|c|c|c|}
\hline \multirow[t]{2}{*}{ Samples No } & \multirow{2}{*}{$\begin{array}{l}\text { \# of } \\
\text { windows } \\
\text { (status) }\end{array}$} & \multirow[t]{2}{*}{$\begin{array}{l}\text { Area of patient } \\
\text { rooms }\left(\mathrm{m}^{2}\right)\end{array}$} & \multirow[t]{2}{*}{$\mathrm{VS}^{\mathrm{a}}$} & \multirow[t]{2}{*}{$\begin{array}{l}\text { Volume } \\
\left(\mathrm{m}^{3}\right)\end{array}$} & \multirow[t]{2}{*}{$\begin{array}{l}\mathrm{T}^{\mathrm{b}} \\
\left({ }^{\circ} \mathrm{C}\right)\end{array}$} & \multirow[t]{2}{*}{$\begin{array}{l}\mathrm{RH}^{\mathrm{c}} \\
(\%)\end{array}$} & \multirow[t]{2}{*}{$\mathrm{CO}_{2}(\mathrm{ppm})$} & \multicolumn{2}{|l|}{$\begin{array}{l}\mathrm{PNC}^{\mathrm{d}} \\
(\min -\max )\end{array}$} \\
\hline & & & & & & & & $\mathrm{d}<5 \mu \mathrm{m}$ & $\mathrm{d}>5-10 \mu \mathrm{m}$ \\
\hline $1^{\mathrm{S}}$ & $3($ close $)$ & 56 & Mechanical/Natural & 168 & 23.2 & 52.6 & 425 & $\begin{array}{l}28,446.2 \\
(27,428-29,831)\end{array}$ & $\begin{array}{l}90.5 \\
(66-135)\end{array}$ \\
\hline $2^{\mathrm{S}}$ & $4($ close $)$ & 81 & Mechanical/Natural & 243 & 22.4 & 52.1 & 445 & $\begin{array}{l}17,802.4 \\
(16,726-18,894)\end{array}$ & $\begin{array}{l}15.4 \\
(6-26)\end{array}$ \\
\hline $3^{\mathrm{S}}$ & 2 (close) & 18 & Mechanical/Natural & 54 & 22.7 & 51.6 & 465 & $\begin{array}{l}27,442.2 \\
(25,521-28,932)\end{array}$ & $\begin{array}{l}116.3 \\
(66-202)\end{array}$ \\
\hline $4^{\mathrm{S}}$ & 4 (close) & 77.4 & Mechanical/Natural & 232.2 & 24.8 & 40.3 & 474 & $\begin{array}{l}17,905.2 \\
(16,825-19,174)\end{array}$ & $\begin{array}{l}16.1 \\
(7-30)\end{array}$ \\
\hline $5^{\mathrm{S}}$ & $3($ close $)$ & 84 & Mechanical/Natural & 252 & 23.8 & 43.7 & 449 & $\begin{array}{l}25,695.5 \\
(24,942-26,719)\end{array}$ & $\begin{array}{l}27.2 \\
(19-37)\end{array}$ \\
\hline $6^{\mathrm{S}}$ & 3 (close) & 64 & Mechanical/Natural & 192 & 22.4 & 42.1 & 465 & $\begin{array}{l}7751.9 \\
(6085-9790)\end{array}$ & $\begin{array}{l}36 \\
(25-50)\end{array}$ \\
\hline $7^{\mathrm{S}}$ & 6 (close) & 400 & Mechanical/Natural & 1200 & 23.5 & 44.4 & 561 & $\begin{array}{l}45,203.5 \\
(35,640-62,780)\end{array}$ & $\begin{array}{l}22.4 \\
(0-45.7)\end{array}$ \\
\hline $8^{\mathrm{S}}$ & $6($ close $)$ & 400 & Mechanical/Natural & 1200 & 24.5 & 53.6 & 411 & $\begin{array}{l}45,203.5 \\
(35,640-62,780)\end{array}$ & $\begin{array}{l}22.4 \\
(0-45.7)\end{array}$ \\
\hline $9^{S}$ & 4 (close) & 179 & Mechanical (HEPA) & 537 & 23.2 & 53.1 & 297 & $\begin{array}{l}39,608.3 \\
(25,051-59,650)\end{array}$ & $\begin{array}{l}4.3 \\
(0-13.3)\end{array}$ \\
\hline $10^{\mathrm{S}}$ & 4 (close) & 179 & Mechanical (HEPA) & 537 & 22.8 & 52.3 & 294 & $\begin{array}{l}39,608.3 \\
(25,051-59,650)\end{array}$ & $\begin{array}{l}4.3 \\
(0-13.3)\end{array}$ \\
\hline $11^{\mathrm{B}}$ & 2 (open) & 18 & Mechanical/Natural & 54 & 28.1 & 30.3 & 471 & $\begin{array}{l}21,425.4 \\
(18,216-27,166)\end{array}$ & $\begin{array}{l}32.9 \\
(20-44)\end{array}$ \\
\hline $12^{\mathrm{B}}$ & 2 (close) & 18 & Mechanical/Natural & 54 & 27.5 & 35.9 & 367 & $\begin{array}{l}21,847.5 \\
(18,670-28,190)\end{array}$ & $\begin{array}{l}34.1 \\
(22-46)\end{array}$ \\
\hline $13^{\mathrm{B}}$ & 2 (open) & 20 & Mechanical/Natural & 60 & 27.8 & 29.5 & 465 & $\begin{array}{l}21,328.6 \\
(18,117-26,955)\end{array}$ & $\begin{array}{l}32.4 \\
(19-43)\end{array}$ \\
\hline $14^{\mathrm{B}}$ & 4 (close) & 350 & Mechanical (HEPA) & 1050 & 26.5 & 26.8 & 380 & $\begin{array}{l}15,217.3 \\
(13,502-18,067)\end{array}$ & $\begin{array}{l}46.8 \\
(15-110)\end{array}$ \\
\hline $15^{\mathrm{B}}$ & 4 (close) & 350 & Mechanical (HEPA) & 1050 & 25.9 & 28.2 & 366 & $\begin{array}{l}15,217.3 \\
(13,502-18,067)\end{array}$ & $\begin{array}{l}46.8 \\
(15-110)\end{array}$ \\
\hline $15^{\mathrm{e}}$ & 2 (open) & 70 & Mechanical/Natural & 210 & 24.2 & 35.6 & 298 & $\begin{array}{l}19,844.5 \\
(17,542-21,398)\end{array}$ & $\begin{array}{l}29.5 \\
(24-36)\end{array}$ \\
\hline
\end{tabular}

$S, B$ Sina hospital, Shahid Beheshti hospital

${ }^{\mathrm{a}}$ Ventilation system

${ }^{\mathrm{b}}$ Temperature

${ }^{\mathrm{c}}$ Relative humidity

${ }^{\mathrm{d}}$ Particle number concentrations (\# of particles/L)

${ }^{\text {ePrivate houses }}$

Table 2 Mean values of temperature, relative humidity, and $\mathrm{CO}_{2}$ concentrations in the studied hospitals

\begin{tabular}{llll}
\hline Hospitals/variables & Temperature & $\begin{array}{l}\text { Relative } \\
\text { humidity }\end{array}$ & $\mathrm{CO}_{2}$ \\
\hline Sina & 23.3 & 48.6 & 428.6 \\
Shahid Beheshti & 27.2 & 30.1 & 409.9 \\
\hline
\end{tabular}

transmitted among people through respiratory droplets and contact routes. Airborne transmission is different from droplet transmission as it refers to the presence of microbes within droplet nuclei, which are generally considered to be particles $<5 \mu \mathrm{m}$ in diameter, which can remain in the air for long periods of time and be transmitted to others over distances greater than $1 \mathrm{~m}$ (WHO, 2020). Hence, in this study, the PNC in the sampling sites was measured in different patient's rooms and wards of the two studied hospitals at different sizes including $>5-10 \mu \mathrm{m}$ and $<5 \mu \mathrm{m}$. The results are presented in Table 1. As can be seen here, the 
concentration of particles with a size of $<5 \mu \mathrm{m}$ was much higher than that of $>5-10 \mu \mathrm{m}$, and the maximum PNC with a diameter less than $5 \mu \mathrm{m}$ was observed in negative pressure isolation wards, which might be due to the high density of hospitalized patients, the medical care activities such as suction and intubation that have the potential of producing fine particles. Moreover, the surface area of the patient's rooms and the number of patients in each room can be considered as the effective parameters in the high PCN, as shown in Table 1. On the other hand, our finding revealed that particles in respiratory droplet sizes $(>5-10 \mu \mathrm{m})$ have low concentrations compared to the size range of the droplet nuclei $(<5 \mu \mathrm{m})$, indicating the presumptive role of these particles in the transmission of respiratory diseases such as COVID-19 in hospitals. Besides, all air samples collected from the hospitals were PCR negative for SARS-CoV-2 (as shown in Table 3). This finding is consistent with the results of Faridi et al. (2020), Ong et al. (2020), and Booth et al. (2005) studies. In the mentioned studies, SARS-CoV-2 was not also detected in the air samples collected from patient's room in hospitals. These results may be attributed to the use of oxygen masks for patients, natural and mechanical ventilation in the studied wards, and environmental factor affecting bioaerosol concentrations. In a related study it has

Table 3 SARS-CoV-2 in the air samples of hospital wards

\begin{tabular}{|c|c|c|c|c|c|c|c|}
\hline \# of samples & $\begin{array}{l}\text { Hospital wards/pri- } \\
\text { vate house }\end{array}$ & $\begin{array}{l}\text { \# of suspected } \\
\text { COVID-19 patients } \\
\text { (status) }\end{array}$ & $\begin{array}{l}\text { \# Of } \\
\text { confirmed } \\
\text { COVID-19 }\end{array}$ & $\begin{array}{l}\text { Status } \\
\text { of the } \\
\text { patients }\end{array}$ & $\begin{array}{l}\text { Treatment methods/ } \\
\text { drugs }^{c}\end{array}$ & \# Of staffs & $\begin{array}{l}\text { SARS-CoV-2 in air } \\
\text { sample }^{\mathrm{d}}\end{array}$ \\
\hline 1 & Infectious room $\# 1^{\mathrm{a}, \mathrm{b}}$ & 5 (Oxygen mask: 5) & 2 & Well & $1,2,3,4,5$ & 1 & Negative \\
\hline 2 & Infectious room $\# 2^{\mathrm{a}, \mathrm{b}}$ & 7 (Oxygen mask: 7) & 1 & Well & $1,2,3,4,5$ & 2 & Negative \\
\hline 3 & Infectious room $\# 3^{\mathrm{a}, \mathrm{b}}$ & 5 (Oxygen mask: 5) & 3 & Well & $1,2,3,4,5$ & 1 & Negative \\
\hline 4 & $\begin{array}{l}\text { Neurology room } \\
\# 2^{\mathrm{a}, \mathrm{b}}\end{array}$ & 6 (Oxygen mask: 6) & 2 & Well & $1,2,3,4,5$ & 2 & Negative \\
\hline 5 & $\begin{array}{l}\text { Neurology room } \\
\# 3^{\mathrm{a}, \mathrm{b}}\end{array}$ & 6 (Oxygen mask: 6) & 1 & Well & $1,2,3,4,5$ & 2 & Negative \\
\hline 6 & $\begin{array}{l}\text { Neurology room } \\
\# 4^{\mathrm{a}, \mathrm{b}}\end{array}$ & 8 (Oxygen mask: 8) & 2 & Well & $1,2,3,4,5$ & 2 & Negative \\
\hline 7 & ICU-Isolation \# $1^{\mathrm{a}, \mathrm{b}}$ & $\begin{array}{l}14 \text { (Oxygen mask: } \\
14)\end{array}$ & 2 & Well & $1,2,3,4,5$ & 4 & Negative \\
\hline 8 & ICU-Isolation \# $1^{\mathrm{a}, \mathrm{b}}$ & $\begin{array}{l}14 \text { (Oxygen mask: } \\
14)\end{array}$ & 2 & Well & $1,2,3,4,5$ & 4 & Negative \\
\hline 9 & $\begin{array}{l}\text { ICU-negative pres- } \\
\text { sure isolation \#1 } 1^{\mathrm{a}, \mathrm{b}}\end{array}$ & $\begin{array}{l}4 \text { (Oxygen mask: } 1, \\
\text { Intubated:3) }\end{array}$ & 1 & Ill:3 & $1,2,3,4,5$ & 2 & Negative \\
\hline 10 & $\begin{array}{l}\text { ICU-negative pres- } \\
\text { sure isolation \#1 } 1^{\mathrm{a}, \mathrm{b}}\end{array}$ & $\begin{array}{l}4 \text { (Oxygen mask: } 1 \text {, } \\
\text { Intubated:3) }\end{array}$ & 1 & Ill:3 & $1,2,3,4,5$ & 2 & Negative \\
\hline 11 & $\begin{array}{l}\text { Pulmonary Diseases } \\
\text { Inpatient room } \\
\# 1^{\mathrm{a}, \mathrm{b}}\end{array}$ & 4 (Oxygen mask: 2) & 2 & Well & $1,2,3,4,5$ & 2 & Negative \\
\hline 12 & $\begin{array}{l}\text { Pulmonary Diseases } \\
\text { Inpatient room } \\
\# 2^{\mathrm{a}, \mathrm{b}}\end{array}$ & 4 (Oxygen mask: 2) & 1 & Well & $1,2,3,4,5$ & 2 & Negative \\
\hline 13 & $\begin{array}{l}\text { Pulmonary Diseases } \\
\text { Inpatient room } \\
\# 3^{\mathrm{a}, \mathrm{b}}\end{array}$ & 5 (Oxygen mask: 2) & 2 & Well & $1,2,3,4,5$ & 2 & Negative \\
\hline 14 & ICU-Isolation \# $1^{\mathrm{a}, \mathrm{b}}$ & $\begin{array}{r}15 \text { (Oxygen mask: } \\
10 \text {, Intubated: } 5 \text { ) }\end{array}$ & 3 & Ill:3 & $1,2,3,4,5$ & 4 & Negative \\
\hline 15 & ICU-Isolation \# $1^{\mathrm{a}, \mathrm{b}}$ & $\begin{array}{r}15 \text { (Oxygen mask: } \\
10, \text { Intubated: } 5 \text { ) }\end{array}$ & 3 & Ill:3 & $1,2,3,4,5$ & 4 & Negative \\
\hline 16 & Patient's houses & $\begin{array}{l}\text { Without oxygen and } \\
\text { protective mask }\end{array}$ & 2,5 & Well & Follow-up visit & - & $\begin{array}{l}2 \text { of } 4 \text { samples were } \\
\text { Positive }\end{array}$ \\
\hline
\end{tabular}

${ }^{\mathrm{a}}$ Impinger technique

${ }^{\mathrm{b}}$ Filtration technique

${ }^{\mathrm{c}} 1$ Oxygen therapy; 2 Interferon; 3 Hemoperfusion; 4 Heparin; 5 Antiviral drugs. Note: depending on the instantaneous status of the patient during the hospitalization, one or more of the mentioned methods might be used

${ }^{\mathrm{d}}$ The results of two various sampling methods including Filter and Impinger techniques, in impinger technique, we used both RPME and DMEM medium to collect air samples 
been reported that the absence of SARS-CoV-2 virus (present or not detected) in related hospital wards can be attributed to several reasons such as the strength of the source (number of infected patients), lack of an standard measurement protocol for airborne viruses, room volume, and the effect of mechanical and natural ventilation in the different places (ventilation rate) (Conte et al. 2021). Grimalt et al. (2022) also assessed the spread of SARS-CoV-2 in hospital areas and found that the highest risk of nosocomial infection might be occurred in the hospital areas that did not directly exposed to the exhaled breath of infected patients, thus the ventilation systems of the hospitals units should be evaluated to minimize the possible contagious influence via the direct monitoring of SARS-CoV-2 in the air.

In a previous study, 58 datasets measuring airborne SARS-CoV-2 RNA traces in the air of hospitals and care facilities showed that 41 datasets were negative for presence of SARS-CoV-2 in a the all air samples or positive (at least one air sample tested positive with PCR analysis) without quantification of concentrations, and 17 datasets $(29.3 \%$ of the total studies) qualitatively examined virus concentrations in the air samples (Dinoi et al., 2021). Moreover, BenShmuel et al. (2020) investigated infectious titers of the virus in 97 positive air and surface samples in order to evaluate SARS-CoV-2 viability, and reported no infectious titers of the virus in the samples. The mentioned study indicated that there is a limited fraction of viable virus in the positive air samples, which implied the SARS-CoV-2 virus is mainly transmitted through respiratory droplets that remain in the air for a short time and can travel a short distance around the patients (Ben-Shmuel et al. 2020).

Pearson's correlation (r) coefficient test was performed to examine the correlation between the environmental variables and the PNC. According to the results, a significant positive correlation was observed between $\mathrm{PNC}_{0-5 \mu \mathrm{m}}$ and relative humidity (RH) with a correlation coefficient value of 0.598 $\left(P^{<} 0.05\right)$. A same correlation was also observed between RH and $\mathrm{PNC}_{5-10 \mu \mathrm{m}}(r=0.016)$; however, it was not significant $(P=0.96)$. Moreover, a negative and non-significant correlation were observed between temperature and both $\mathrm{PNC}_{0-5}$ um and $\mathrm{PNC}_{5-10 \mu \mathrm{m}}$ values $\left(P^{>} 0.05\right)$. It has been also reported that low temperature increases the visibility and transmission of SARS-CoV through the air. Based on the statistical analysis, $\mathrm{CO}_{2}$ concentration and $\mathrm{PNC}_{0-5}$ um was negatively correlated $(r=-0126, P=0.65)$, which might be due to the fact that proper ventilation could decrease the values of $\mathrm{CO}_{2}$ concentration and PNC, simultaneously. In general, the effect of the environmental parameters on the results is not well known.

However, two positive air samples were identified that collected from indoor air of the house of a family with five members infected with SARS-CoV-2 who were nonhospitalized due to their disease status and according to physicians' advice, but are only required to be home quarantined to prevent community transmission. The results were interpreted semi-quantitatively using the Cycles of threshold $(\mathrm{Ct})$ method for each target. $\mathrm{Ct}$ value $\leq 40$ indicates positive result for each target among 45 cycles, and $\mathrm{Ct}$ value $>40$ indicates negative result, which considered as analytical sensitivity or limit of detection (LOD). The Ct values of two positive samples were $35.4,36.3$, and $37.4,37.8$, respectively that correspond to $\mathrm{N}$ and ORF1ab target genes. The positive samples were collected with PTFE filter in conjunction with a cassette. This result indicated that the PTFE filter acts as a better sampler compared to the impinger like samplers for the sampling of SARS-CoV-2 virus. However, it is not a definitive conclusion and may be influenced by various factors such as sample numbers, sampling frequency and intervals, etc. The sampling set up was placed in a height of $1.5 \mathrm{~m}$ above the floor and the patients did not wear oxygen or protective face masks in their house. This result may be associated with sneezing or coughing of patients near the filters. The air samples collected from the patient's houses by impinger were all negative (Table 3). This result is consistent with some previous studies that have isolated this virus from air samples. For example, Guo et al. (2020) identified the SARS-CoV-2 virus in a distance of $4 \mathrm{~m}$ from patients in the air samples collected from hospital. In the present study, the air samples were collected from various distances from patients using two different samplers, including PTFE and impinger. This difference may be attributed to interfering factors such as ventilation in sampling sites, patient density, wearing oxygen and protective face masks by patients, patients' activities and sampling conditions. Moreover, Liu et al. (2020) reported a high concentration of this virus in toilet areas used by patients and crowded wards in hospitals. It should be noted that in some studies with positive PCR results for SARS-CoV-2 in air collected samples, the hospitalized patients were asked not to wear a face mask (Booth et al., 2005), this can be a reason for such observations. It should also be noted that none of the family members with a positive air sample wear the mask. Detection of the virus in the private house of the patients may be attributed to the lack of use of face masks by the non-hospitalized patients and lack of ventilation systems in their private houses.

Some limitations in the present study included lack of possibility to sample air in the rooms occupied with patients without oxygen masks, lack of the possibility to use sampling pumps with higher flow rate, and lack of the possibility to quantify the number of viruses in the positive sample. 


\section{Conclusion}

This research aimed at investigating the presence of SARSCoV-2 in the indoor air of two major hospitals in Hamadan, Iran. For this reason, various air samples were collected using two different sampling methods including PTFE filter membrane in conjunction with a cassette and impinger containing VTM. According to the results, a very high concentration of particles in the size range of droplet nuclei $(<5 \mu \mathrm{m})$ was identified compared to particles in the size range of respiratory droplets $(>5-10 \mu \mathrm{m})$ in the areas where patients were hospitalized. This may be due to the use of oxygen and surgical masks by patients in the studied hospitals. The results implied that despite the high concentration of particles in the size range of droplet nuclei, all air samples were PCR negative for SARS-CoV-2, indicating the presumptive role of these particles in the transmission of respiratory diseases such as COVID-19 in hospitals. Two of four air samples collected from indoor air of the house of nonhospitalized patients were PCR positive for SARS-CoV-2. These positive air samples were collected from indoor air of a house of family with five members infected with SARSCoV-2. Our findings indicated that the PTFE filter membrane in conjunction with a cassette might be more effective for determining SARS-CoV-2 in air compared to impinger containing VTM. However, further studies are required to evaluate the differences between the two sampling methods because our results are not sufficient to propose a robust conclusion. Also, it can be concluded that using face mask by patients can prevent the release of viruses into the indoor air, even in hospitals with a high density of patients.

Acknowledgements The research was financially supported by the Vice Chancellery for Research at Hamadan University of Medical Sciences (Grant No. 990223988). We thank the staff of Sina and Shahid Beheshti Hospitals.

Data Availability The data that support the findings of this study are available from the corresponding author upon reasonable request.

\section{Declarations}

Conflict of interest The authors declare no conflicts of interest.

\section{References}

Belosi, F., Conte, M., Gianelle, V., Santachiara, G., \& Contini, D. (2021). On the concentration of SARS-CoV-2 in outdoor air and the interaction with pre-existing atmospheric particles. Environmental Research, 193, 110603. https://doi.org/10.1016/j.envres. 2020.110603

Ben-Shmuel, A., Brosh-Nissimov, T., Glinert, I., Bar-David, E., Sittner, A., Poni, R., Cohen, R., Achdout, H., Tamir, H., \& YahalomRonen, Y. (2020). Detection and infectivity potential of severe acute respiratory syndrome coronavirus 2 (SARS-CoV-2) environmental contamination in isolation units and quarantine facilities. Clinical Microbiology and Infection, 26, 1658-1662.

Booth, T. F., Kournikakis, B., Bastien, N., Ho, J., Kobasa, D., Stadnyk, L., Li, Y., Spence, M., Paton, S., \& Henry, B. (2005). Detection of airborne severe acute respiratory syndrome (SARS) coronavirus and environmental contamination in SARS outbreak units. The Journal of Infectious Diseases, 191, 1472-1477.

Chan, K. H., Peiris, J. S. M., Lam, S. Y., Poon, L. L. M., Yuen, K. Y., $\&$ Seto, W. H. (2011). The effects of temperature and relative humidity on the viability of the SARS coronavirus. Advances in Virology, 2011, 734690. https://doi.org/10.1155/2011/734690

Chartier, Y., \& Pessoa-Silva, C. (2009). Natural ventilation for infection control in health-care settings. World Health Organization.

Conte, M., Feltracco, M., Chirizzi, D., Trabucco, S., Dinoi, A., Gregoris, E., Barbaro, E., La Bella, G., Ciccarese, G., Belosi, F., La Salandra, G., Gambaro, A., \& Contini, D. (2021). Airborne concentrations of SARS-CoV-2 in indoor community environments in Italy. Environmental Science and Pollution Research. https:// doi.org/10.1007/s11356-021-16737-7

Dhand, R., \& Li, J. (2020). Coughs and sneezes: Their role in transmission of respiratory viral infections, including SARS-CoV-2. American Journal of Respiratory Critical Care Medicine, 202, 651-659.

Dinoi, A., Feltracco, M., Chirizzi, D., Trabucco, S., Conte, M., Gregoris, E., Barbaro, E., La Bella, G., Ciccarese, G., Belosi, F., La Salandra, G., Gambaro, A., \& Contini, D. (2021). A review on measurements of SARS-CoV-2 genetic material in air in outdoor and indoor environments: Implication for airborne transmission. Science of the Total Environment. https://doi.org/10. 1016/j.scitotenv.2021.151137

Faridi, S., Niazi, S., Sadeghi, K., Naddafi, K., Yavarian, J., Shamsipour, M., Jandaghi, N. Z. S., Sadeghniiat, K., Nabizadeh, R., \& Yunesian, M. (2020). A field indoor air measurement of SARS-CoV-2 in the patient rooms of the largest hospital in Iran. Science of the Total Environment, 725, 138401.

Grimalt, J. O., Vílchez, H., Fraile-Ribot, P. A., Marco, E., Campins, A., Orfila, J., van Drooge, B. L., \& Fanjul, F. (2022). Spread of SARS-CoV-2 in hospital areas. Environmental Research, 204, 112074. https://doi.org/10.1016/j.envres.2021.112074

Guo, Z.-D., Wang, Z.-Y., Zhang, S.-F., Li, X., Li, L., Li, C., Cui, Y., Fu, R.-B., Dong, Y.-Z., \& Chi, X.-Y. (2020). Aerosol and surface distribution of severe acute respiratory syndrome coronavirus 2 in hospital wards, Wuhan, China, 2020. Emerging Infectious Diseases, 26, 1586.

Holshue, M. L., DeBolt, C., Lindquist, S., Lofy, K. H., Wiesman, J., Bruce, H., Spitters, C., Ericson, K., Wilkerson, S., Tural, A., Diaz, G., Cohn, A., Fox, L., Patel, A., Gerber, S. I., Kim, L., Tong, S., Lu, X., Lindstrom, S., ... Pillai, S. K. (2020). First case of 2019 novel coronavirus in the United States. New England Journal of Medicine, 382, 929-936. https://doi.org/10. 1056/NEJMoa2001191

Kenarkoohi, A., Noorimotlagh, Z., Falahi, S., Amarloei, A., Mirzaee, S. A., Pakzad, I., \& Bastani, E. (2020). Hospital indoor air quality monitoring for the detection of SARS-CoV-2 (COVID-19) virus. Science of the Total Environment, 748, 141324.

Liu, Y., Ning, Z., Chen, Y., Guo, M., Liu, Y., Gali, N. K., Sun, L., Duan, Y., Cai, J., \& Westerdahl, D. (2020). Aerodynamic analysis of SARS-CoV-2 in two Wuhan hospitals. Nature, 582(7813), 557-560.

Morawska, L., \& Cao, J. (2020). Airborne transmission of SARSCoV-2: The world should face the reality. Environment International, 139, 105730.

Ong, S. W. X., Tan, Y. K., Chia, P. Y., Lee, T. H., Ng, O. T., Wong, M. S. Y., \& Marimuthu, K. (2020). Air, surface environmental, and personal protective equipment contamination by severe 
acute respiratory syndrome coronavirus 2 (SARS-CoV-2) from a symptomatic patient. JAMA, 323(16), 1610-1612.

Onmek, N., Kongcharoen, J., Singtong, A., Penjumrus, A., \& Junnoo, S. (2020). environmental factors and ventilation affect concentrations of microorganisms in hospital wards of Southern Thailand. Journal of Environmental Public Health. https://doi. org/10.1155/2020/7292198

Poormohammadi, A., \& Azarian, G. (2020). Training manual for prevention of Covid-19 disease among hospital personnel. Journal of Education and Community Health, 7, 69-71. https://doi.org/ 10.29252/jech.7.2.69

Rahmani, A. R., Leili, M., Azarian, G., \& Poormohammadi, A. (2020). Sampling and detection of corona viruses in air: A mini review. Science of the Total Environment, 740, 140207. https:// doi.org/10.1016/j.scitotenv.2020.140207

Sanchis, A. G., Pashley, R., \& Ninham, B. (2019). Virus and bacteria inactivation by $\mathrm{CO} 2$ bubbles in solution. NPJ Clean Water, 2, $1-9$.

Shereen, M. A., Khan, S., Kazmi, A., Bashir, N., \& Siddique, R. (2020). COVID-19 infection: Origin, transmission, and characteristics of human coronaviruses. Journal of Advanced Research, 24, 91-98. van Doremalen, N., Bushmaker, T., Morris, D. H., Holbrook, M. G., Gamble, A., Williamson, B. N., Tamin, A., Harcourt, J. L., Thornburg, N. J., \& Gerber, S. I. (2020). Aerosol and surface stability of SARS-CoV-2 as compared with SARS-CoV-1. New England Journal of Medicine, 382, 1564-1567.

WHO. (2020). Modes of transmission of virus causing COVID-19: implications for IPC precaution recommendations: scientific brief, 27 March 2020. World Health Organization.

Zheng, J. (2020). SARS-CoV-2: An emerging coronavirus that causes a global threat. International Journal of Biological Sciences, 16, 1678-1685. https://doi.org/10.7150/ijbs.45053

Publisher's Note Springer Nature remains neutral with regard to jurisdictional claims in published maps and institutional affiliations. 